УДК 94 (477)

DOI: $10.33099 / 2707-1383-2020-38-4-5-16$

Сегеда С.П., доктор історичних наук, доиент, начальник науково-дослідного ичентру воєнної історії,

Національний університет оборони України імені Івана Черняховського (м. Київ, Україна) ORCID: https://orcid.org/0000-0002-7763-1324

Андріяко А.М., заступник начальника відділу морально-психологічного забезпечення, Національний університет оборони України імені Івана Черняховського (м. Київ, Украӥна)

\title{
ВІЙСЬКОВО-ІСТОРИЧНИЙ МУЗЕЙ — РЕАЛЬНА ЧАСТИНА БУТТЯ НАЦІОНАЛЬНОГО УНІВЕРСИТЕТУ ОБОРОНИ УКРАЇНИ IМЕНІ ІВАНА ЧЕРНЯХОВСЬКОГО
}

\begin{abstract}
Національний університет оборони України імені Івана Черняховського (НУОУ) вищий військовий навчальний заклад, щзо має унікальні експонати в колекиії свого військово-історичного музею. Тут знаходяться особисті речі людей, які працювали та навчалися в університеті. А також холодна і вогнепальна зброя, військова техніка часів Другої світової війни та сучасності. Кожен експонат музею має власну унікальну історію.
\end{abstract}

Керівниками музею НУОУ були полковник запасу I. М. Мешков (1992-2006), підполковник С.М. Іваненко (2006-2008), полковник А.М. Андріяко (2008-2014), прачівник Збройних Сил М.О. Ткаченко (з 2014 і по теперішній час).

Серед експонатів музею є 592 унікальних світлини, на яких зафіксовано життєдіяльність університету з часів його заснування як військової освітньо-наукової установи до сьогодення.

У Книзі почесних гостей музею залишили захопливі відгуки міністри оборони, начальники генеральних штабів Украӥни та зарубіжжя, представники українських та закордонних військових навчальних закладів, мери міст України, відомі політики. Нині з військовою історією Національного університету оборони України імені Івана Черняховського, яку ілюструють експонати музею, мають можливість ознайомитися відвідувачі з усієї України, іноземні делегації, щзо бувають із візитами у Національному університеті оборони України імені Івана Черняховського, молодь та школярі Києва.

Ключові слова: військово-історичний музей, колекція, вогнепальна зброя, холодна зброя, експозииія.

Військово-історичний музей Національного університету оборони України імені Івана Черняховського був створений 25 липня 1992 року на базі музею Військо- вої академії протиповітряної оборони Сухопутних військ СССР імені маршала Радянського Союзу О.М. Василевського. Він діє відповідно до нормативно-правової бази, 


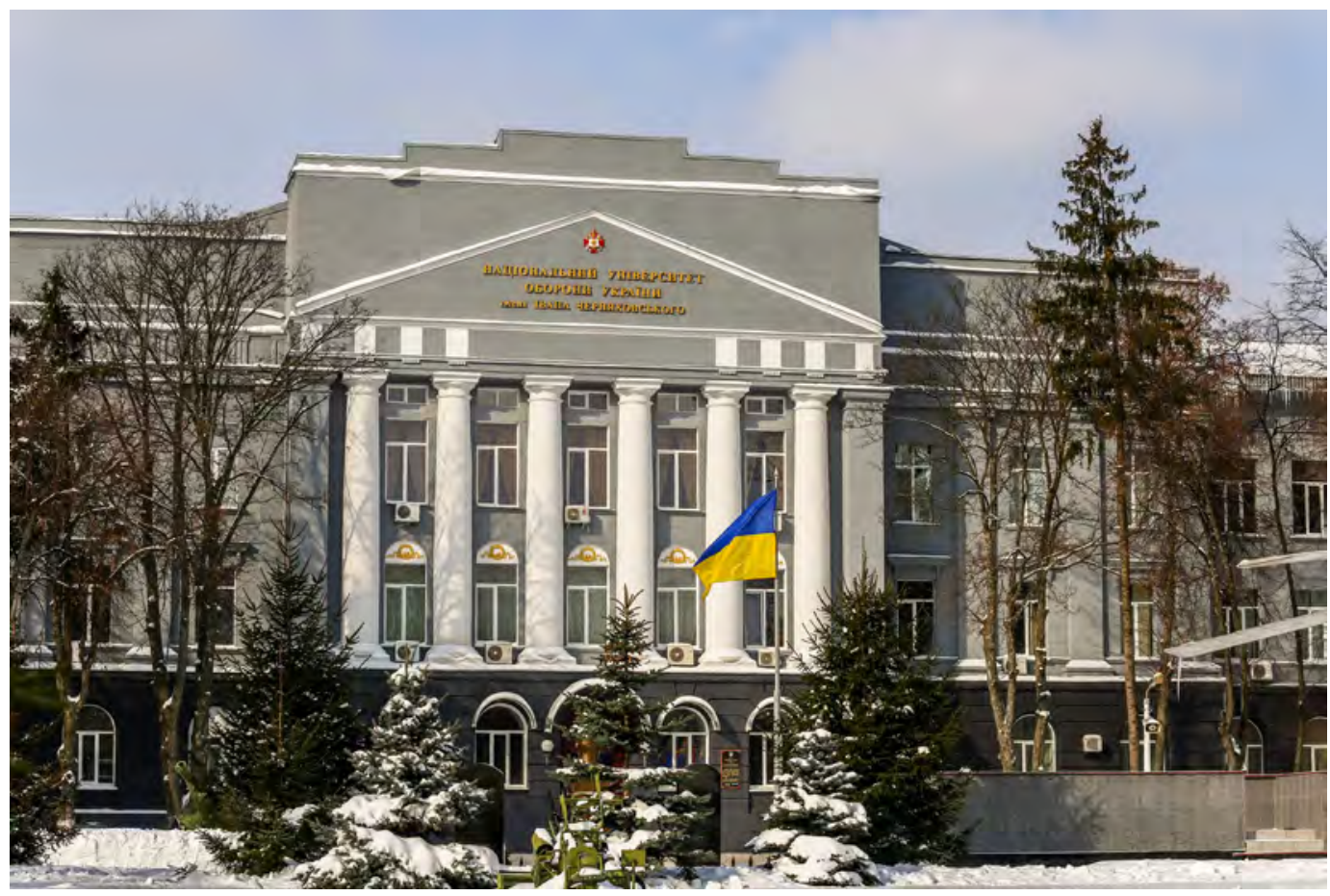

яка регулює діяльність музейних закладів України $[1 ; 2 ; 3]$. Нині музей розташований у п'ятому навчальному корпусі університету. В ньому знаходяться близько 911 музейних експонатів основного та науково-допоміжного фондів.

Військово-історичний музей ставить перед собою завдання не тільки збереження музейних колекцій та популяризації історії навчального закладу, але й організацію і проведення військово-патріотичної роботи як із особовим складом університету, так і $з$ цивільним населенням і гостями столиці. Музей розповідає відвідувачам про славне минуле Збройних Сил України та героїчне сьогодення їх боротьби за територіальну цілісність і незалежність держави.

Працівники музею НУОУ дбають про залучення особового складу навчального закладу, громадян України до надбань національної військової історико-культурної спадщини, що сприяє бойовій підготовці, науковій, педагогічній діяльності особового складу університету, популяризації військової історії. Водночас музей є зразком для слухачів та курсантів університету в орга- нізації музейної справи за їх майбутнім місцем служби, тут відбувається ознайомлення зі збором, систематизацією і збереженням для нащадків матеріалів сучасних подій, які незабаром стануть історією. Практична діяльність музею НАОУ спрямована на культурно-освітню та інформаційно-довідкову роботу, виявлення, збір предметів музейного значення та створення умов для їх збереження. Важливою метою є компонування експозицій таким чином, щоб досягти об'єктивного відображення військово-історичних та соціальних процесів, подій та явищ минулого і сучасності.

Першим начальником музею у 19922006 роках був полковник у запасі I.M. Мешков, за часів керівництва якого було переоформлено, реставровано та осучаснено експозиції, які пропонувалися відвідувачам колишнього музею Військової академії протиповітряної оборони Сухопутних військ імені О.М. Василевського. Також було створено нові експозиції, присвячені діяльності та особовому складу Академії Збройних Сил України, з 1999 року Національної академії оборони України (НАОУ). 


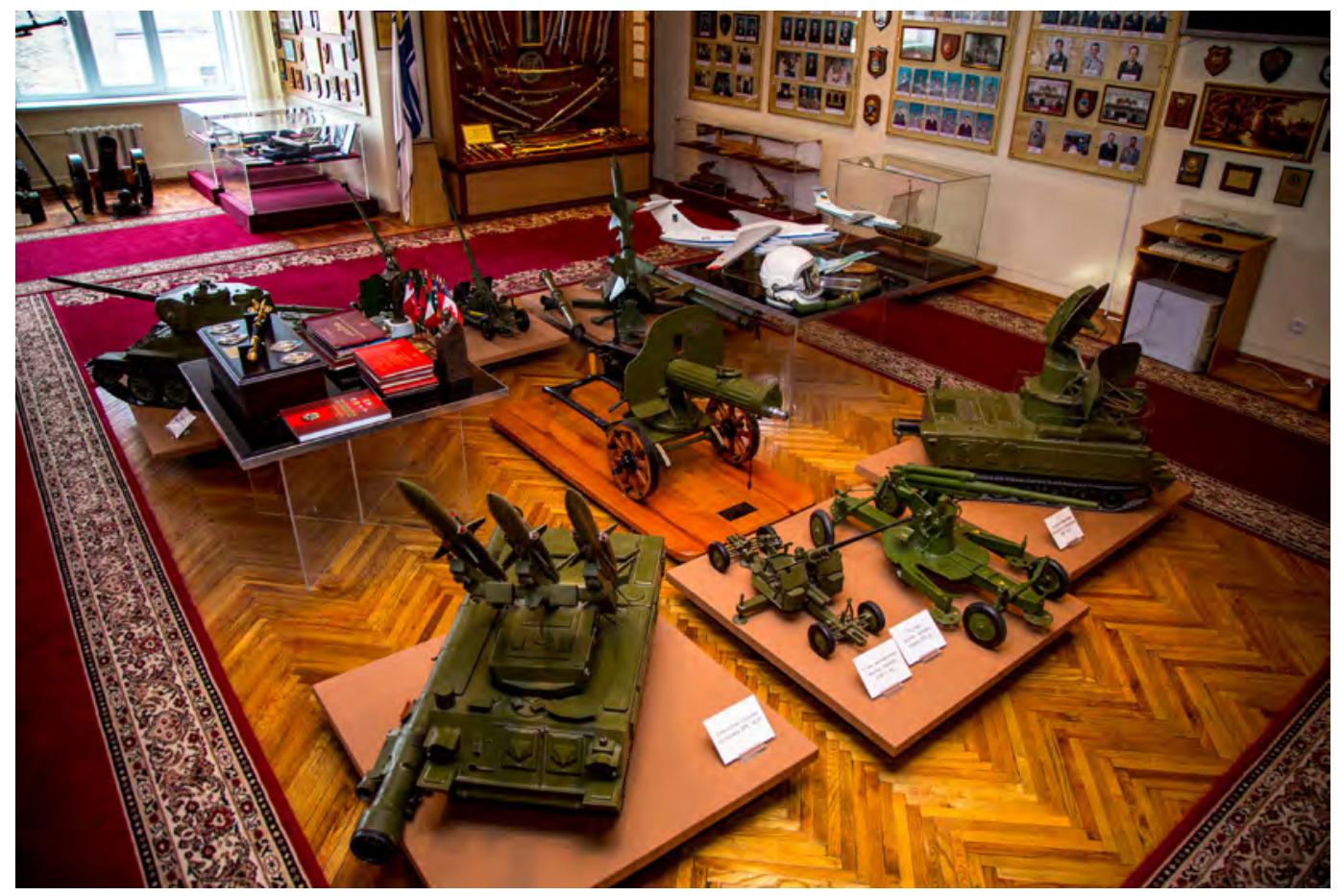

Наступник I.M. Мешкова підполковник С.М. Іваненко (2006-2008 рр.) 3 колективом працівників музею підтримував всі експозиції в належному стані, постійно оновлював експонатами, що знаменували важливі віхи в діяльності НАОУ та житті нашої держави, вів активну роботу 3 військово-патріотичного виховання.

32008 по 2014 рік очолював музей полковник А.М. Андріяко. На ці роки випали події, складні для долі будь-якого музею: заклад змінив місце розташування. Всі експозиції музею було перевезено в інше приміщення, а виставку техніки передислоковано на нові місця. Водночас було оновлено дизайн 3 використанням сучасних матеріалів.

32014 року і по теперішній час керує музеєм працівник Збройних Сил України М.О. Ткаченко. Участь особового складу НУОУ у відсічі агресії Російської Федерації була відображена в експозиції, присвяченій учасникам антитерористичної операції / операції Об'єднаних сил, зокрема, створено експозицію, присвячену Героям
України. Відзначення сторіччя Української революції 1917-1921 років зумовило появу нової експозиції, у якій висвітлено історичний розвиток війська України. Постійно оновлюються фотовиставки, присвячені урочистій церемонії випуску слухачів, особливим подіям життєдіяльності Національного університету оборони України імені Івана Черняховського.

Історія НУОУ простежується і в стендах, де містяться фотографії всіх начальників вищого військового навчального закладу від його заснування до сьогодні: генерал-лейтенанта В.Д. Борискіна (19921997); генерал-лейтенанта О.П. Романенка (1997-1999); генерал-полковника В.М. Палія (1999-2000); генерал-полковника В.Д. Толубка (2000-2005); генерала армії України В.Г. Радецького (2005-2010); генерал-лейтенанта В.М. Телелима (20102016); генерал-полковника Г.П. Воробйова (2016-2017); генерал-лейтенанта А.М. Сиротенка, що очолює університет з 2017 року по цей час. В експозиції містяться й особисті речі керівників НУОУ. 


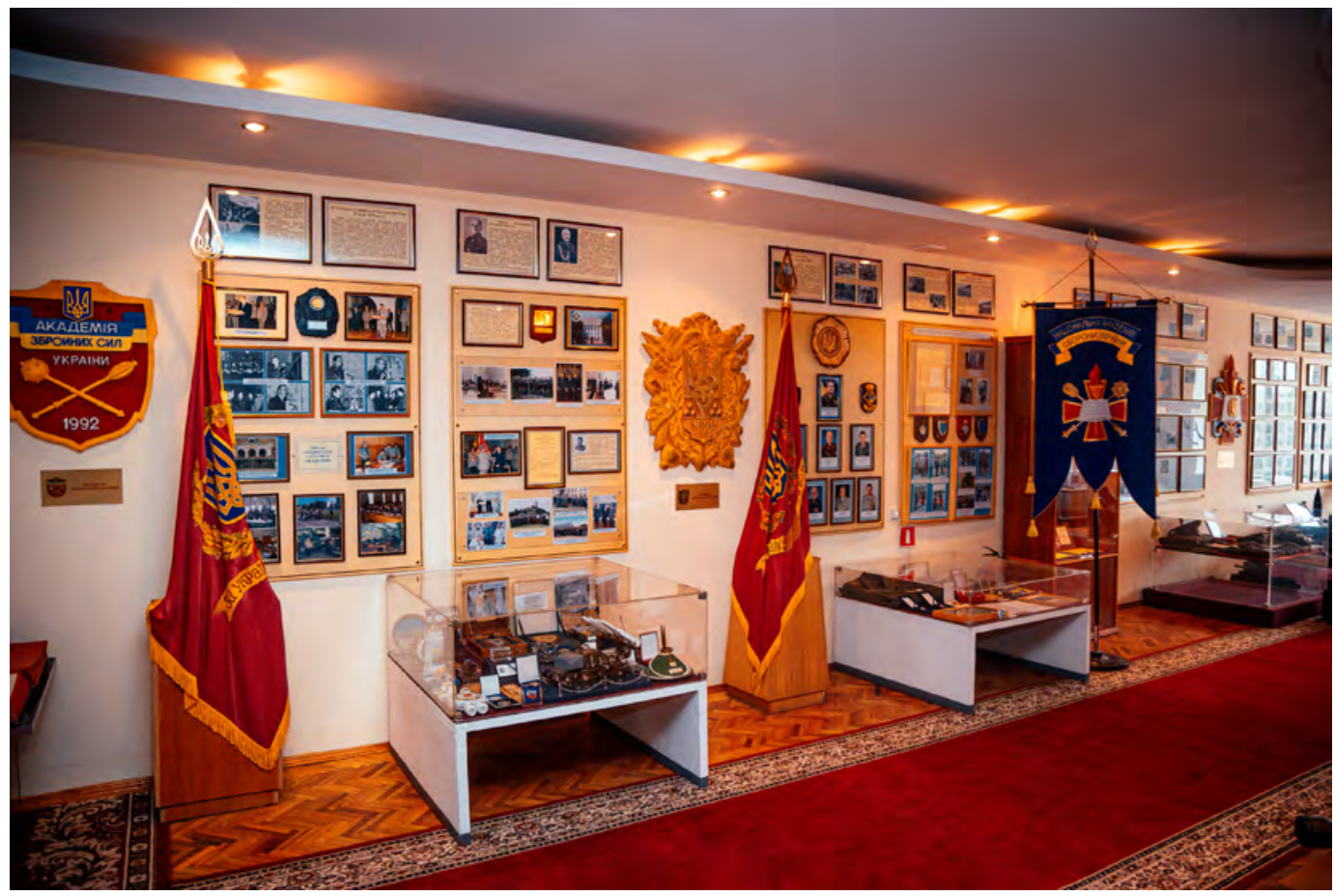

У музеї оформлено 15 виставкових шаф, в яких знаходяться подарунки від представників іноземних делегацій, що відвідували університет з робочими та дружніми візитами. У Книзі почесних гостей музею залишили захопливі відгуки міністри оборони, начальники генеральних штабів України, Китаю, Азербайджану та інших країн, представники українських та закордонних військових навчальних закладів, мери міст України, відомі політики.

Життєдіяльність університету 3 часів його заснування як військової освітньо-наукової установи до сьогодення зафіксовано у 592 унікальних світлинах. Кожен випускник цього навчального закладу, починаючи від першого випуску 1996 року, може знайти інформацію про себе у матеріалах музею. Експонати розкривають окремі віхи вищого військового навчального закладу. Лише експозиція військової форми висвітлює цілий історичний пласт. Так в музеї експонується парадно-вихідна форма маршала Радянського Союзу О.М. Василевського, іменем якого називався навчальний заклад-попередник, що знаходився на цьо- му місці. Плащ-пальто першого начальника Академії Збройних Сил України генерал-лейтенанта В.Д. Борискіна - експонат із історії війська нашої незалежної держави, яка прямує власним шляхом. Форма першого начальника Офісу зв'язку НАТО в Україні капітана першого рангу Лі Меріка - не просто черговий елемент військового одягу, він вносить певний акцент у спрямування інтересів України до партнерства 3 Північно-Атлантичним альянсом. Повсякденний кітель Героя України генерал-майора А.Т. Ковальчука, учасника АТО, випускника університету, символізує сучасну історію боротьби ЗС України проти агресії Російської Федерації.

Відвідувачів музею, як правило, цікавить колекція з 38 зразків холодної зброї. Серед цих експонатів більша частина зібрана та подарована в 1999 році генералом армії України О.I. Кузьмуком, на той час Міністром оборони України. Решту експонатів склали зразки, подаровані колишнім курсантом артилерійського училища генерал-майором П.М. Барським та випускником Академії, національним 


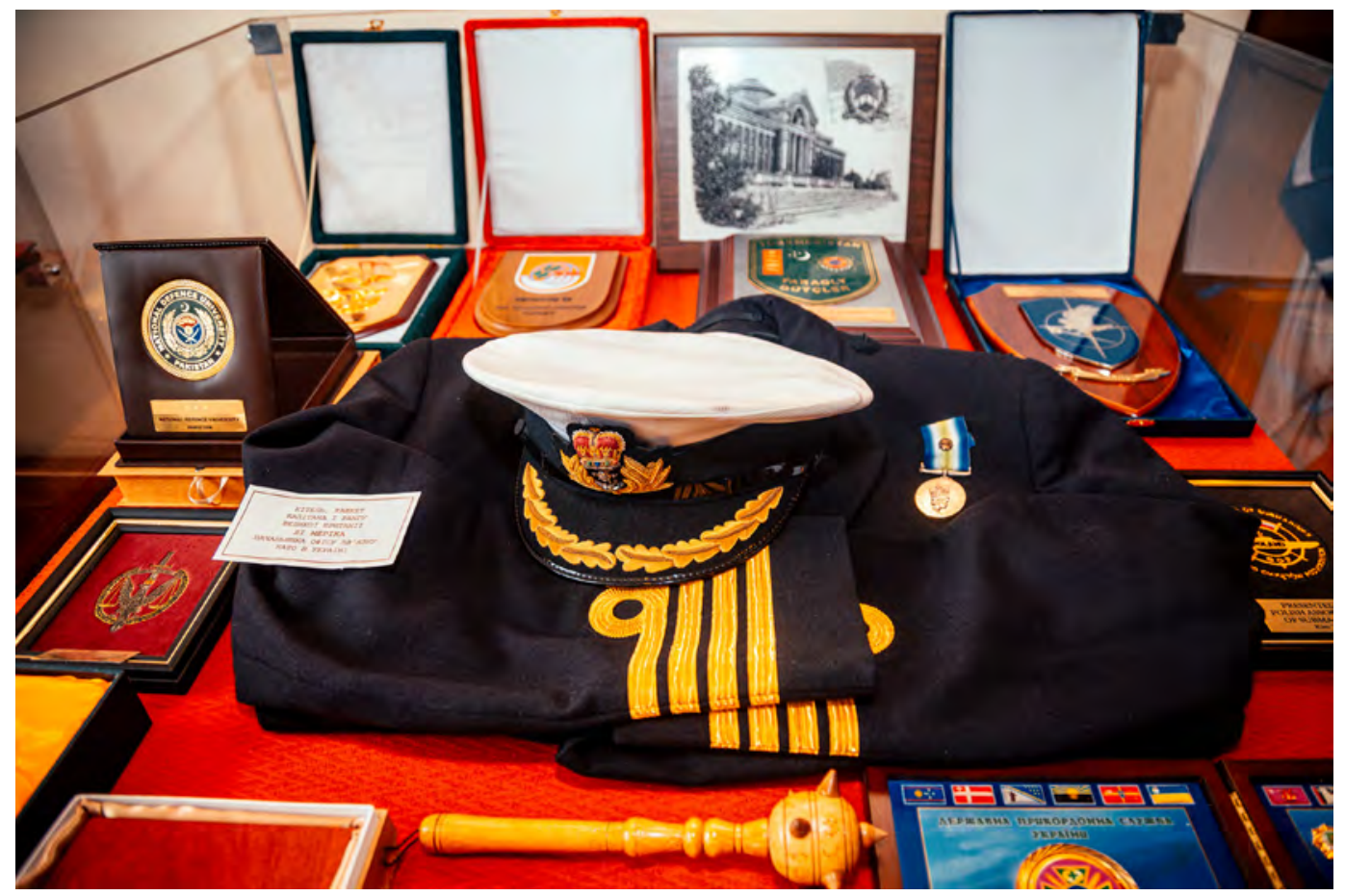

героєм Азербайджану генерал-лейтенантом Акперовим Ровшаном Тельман огли. Зокрема, цікавим експонатом вважається офіцерська піхотна шабля зразка 1913 року, яка має загальну довжину 935 мм, довжина клинка з рукояттю - 870 мм, ширина клинка біля п'яти - 30 мм, товщина обуха в найбільш широкій частині складає 5 мм. Клинок шаблі стальний кований, 3 середнім вигином смуги, з загостреним внутрішнім краєм та гострим бойовим кінцем 3 одним долом у центральній частині та двома у верхній частині полотна. Поверхня полотна вкрита шаром нікелю з трафаретними травленими малюнками. За своїми властивостями клинок шаблі був призначений для рубання та колючих дій. Ефес шаблі складається 3 п'яти частин, рукояті чорного кольору з поглибленням у вигляді борозенок (для кращого утримання в руці).

Серед зразків холодної зброї $\epsilon$ і символічні нагороди. У 1996 році в рамках міжнародного військового співробітництва королевою Великобританії Слизаветою II започатковано традицію щорічного нагородження почесним перехідним мечем коро- леви найбільш успішного випускника університету оперативно-стратегічного рівня підготовки. Перехідний почесний меч являє собою копію палаша офіцерського піхотного зразка 1897 епохи короля Георга V (правив у 1910-1936 роках). Загальна довжина палаша складає 1025 мм, довжина клинка з рукояттю - 987 мм, ширина клинка біля п’яти - 25 мм. Клинок палаша стальний нікельований, прямий, від середини полотна одне лезо (бойовий кінець складає два леза), з широким долом. Сторони полотна покриті травленим візерунком з елементами геральдики - вензелями Георга V під королівською короною. Ефес палаша складається з прямої рукояті, обтягнутою шкірою, та стальної гарди. Гарда зроблена широкою дужкою, яка переходить в захисну чашку з вензелем Георга $\mathrm{V}$ під королівською короною з правого боку. Піхви палаша дерев'яні, обтягнуті шкірою, 3 металевим устям, портупейними ременями зі шкіри. Палаш вироблявся англійською фірмою HAWKSWORTH в Шеффілді, засновником якої був майстер збройових справ Джозеф Хоуксворт (Joseph Hawksworth). 


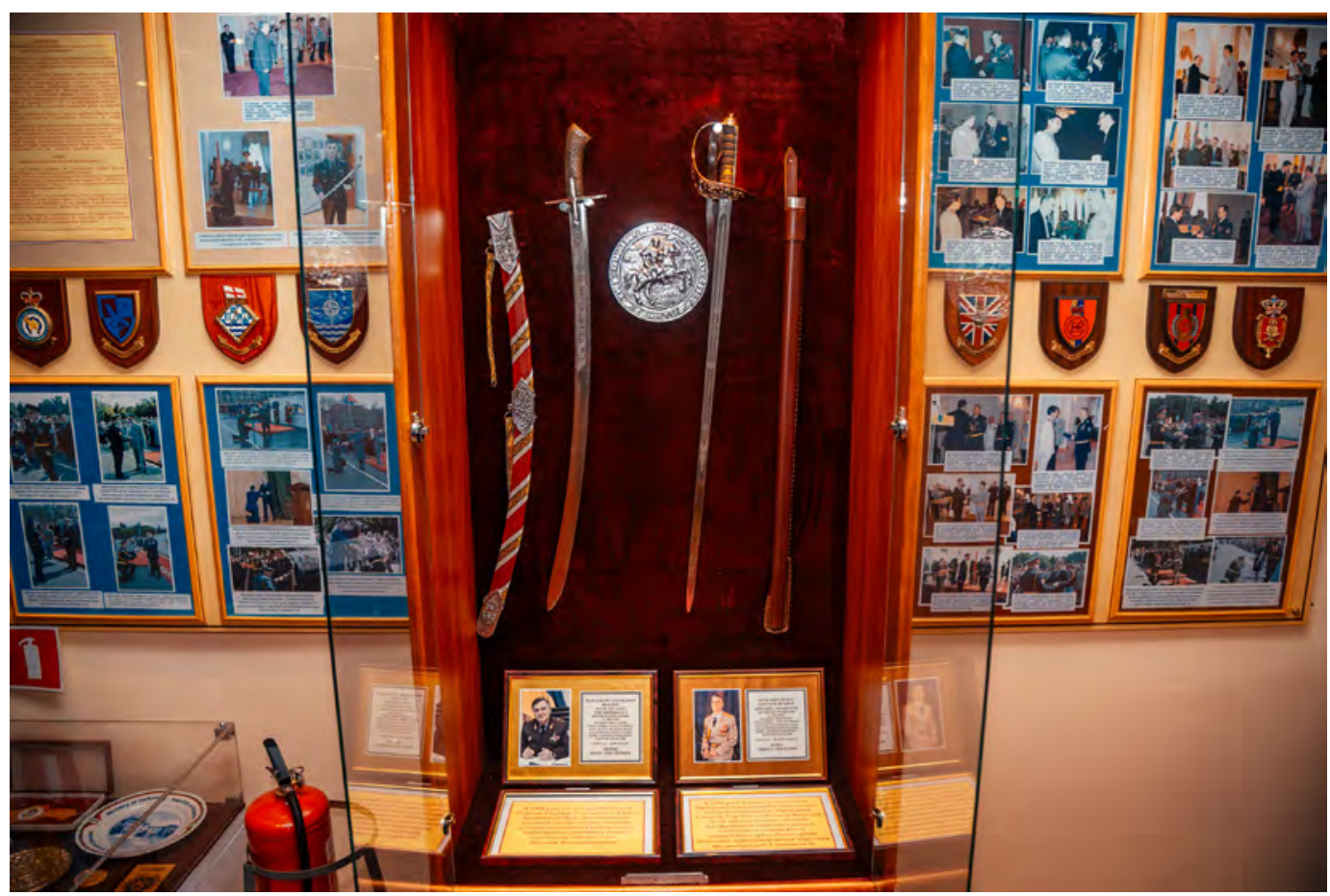

Значне місце серед зразків холодної зброї посідає перехідна шабля часів Богдана Хмельницького, історія появи якої пов'язана з музеєм Національної академії оборони України. У 2008 році під час відвідин музею тогочасний міністр оборони Ю.І. Схануров зауважив, що поряд з мечем королеви Слизавети II відсутня відповідна українська нагорода і варто іï заснувати. I в 2009 році відповідно до наказу Міністра оборони України було запроваджено традицію нагородження перехідною шаблею часів Богдана Хмельницького найбільш успішного випускника університету оперативно-тактичного рівня підготовки. В ході вивчення зброєзнавчої літератури, a також дослідження державних та приватних колекцій холодної зброї при виготовленні шаблі за основу було взято зображення на гравюрі 1654 року голландського художника Гондиюса. Копія бойової шаблі XVII століття старопольського типу викувана та відшліфована вручну. Шабля виготовлена з марганцевистої сталі марки «65г» найближчого аналогу булату. Вважають, що за правильної термообробки та зато- чування, такою шаблею можна розрубати не лише вершника 3 конем, але й сучасний автомобіль. Гравірування-травлення виконувалося царською горілкою. Руків'я зроблено з чорного горіха та декоровано різьбленням, що імітує плетиво. Верх руків'я повторює оригінал, його виконано зі срібла у вигляді медальйону.

Перехідний меч королеви Великобританії Єлизавети II і перехідна шабля часів Богдана Хмельницького зберігаються в одній експозиції.

Зразки вогнепальної зброї та боєприпасів попереднього століття займають центральне місце в експозиції музею. Серед них: кулемет «Максим» зразка 1910 року, крупнокаліберний кулемет ДШК зразка 1938 року, ПЗРК (переносний зенітно-ракетний комплекс) «Стріла-1», навчально-тренувальні постріли різних калібрів. Для наочності і порівняння представлені макети гармат козацької доби.

Юних відвідувачів музею особливо цікавлять виставлені в центрі експозиції макети різних зразків військової техніки (танк T-34, пускова зенітно-ракетна установка, 
станція наведення ракет комплексу «Куб», пускова зенітно-ракетна установка комплексу «С-75»). Кафедра військово-морських сил НАОУ подарувала музею макет бойового корабля «чайка» часів козацької доби, виконаний в масштабі 1:32. Це безпалубний човен запорізьких козаків XVIXVII ст. Натуральна довжина - близько 18 м, ширина й висота бортів - до 4 м. Ззовні для захисту бортів від стріл і куль кріпився пояс із очерету. Чайки мали поперечні переборки й лави, щоглу 3 вітрилом, 10-15 пар весел, носове і кермові весла, вміщували до 70 осіб. Озброєння 4-6 фальконетів (гармат калібру 30 мм).

29 квітня 2000 року за ініціативи Мiністра оборони України генерала армії України О.І. Кузьмука на території НАОУ було облаштовано два відкриті майданчики, що ввійшли до складу музею. На них розташували музейні експонати військової техніки і озброєння. Експозиція була створена за участі генерал-лейтенанта В.М. Палія, на той час начальника Національної академії оборони України, а також заступника начальника академії з виховної роботи генерал-майора О.В. Костюка, начальника музею академії полковника у запасі I.M. Мешкова, завідуючого філії музею працівника ЗС України С.Є.Борисенка.

На відкритих майданчиках музею знаходиться 62 музейних експонати техніки і озброєння. Зокрема, артилерійське озброєння: дві 45-мм гармати зразка 1937 року; 45-мм гармата зразка 1942 року; дві 57-мм гармати ЗИС-2 зразка 1943 року; дві 76мм гармати ЗИС-3; 85-мм гармата Д-44; 122-мм гаубиця М-30 зразка 1938 року; дві 122-мм гаубиці Д-30; 120-мм міномет зразка 1938 року; самохідні артилерійські установки - 122-мм 2С1 «Гвоздика» та 152-мм 2С3 «Акація»; 82-мм міномет 2Б9 «Васильок»; колесний хід В-20 до ПМ-38; 120-мм міномет 2С9 «Нона»; 160-мм міно- мет М-160; 240-мм міномет М-240; бойова машина БМ-13 зразка 1941 року, відома як «Катюша»; 122-мм БМ-21 «Град»; 9П148 «Конкурс»; 9П133 «Флейта».

Також на відкритих майданчиках можна оглянути зенітно-ракетне озброєння. А саме: виріб 2П24 «Круг»; виріб 2П25 «Куб»; виріб 9П31 «Стріла-1»; виріб 9П34 «Стріла-10»; виріб 9А33БМ «Оса АКМ»; виріб 2С6 «Тунгуска»; виріб ЗСУ23-4 «Шилка»; виріб ЗУ23-2; виріб ЗПУ-2; 37-мм зенітну гармату зразка 1939 року; 57-мм АЗПС-60; 85-мм зенітну гарматузразка 1939 року; 100-мм зенітну гармату КС-19.

Відвідувачі можуть ознайомитися 3 музейними експонатами ракет: оперативно-тактичною ракетою комплексу «Скад», тактичними ракетами комплексів «Марс», «Філін», турбонасосним агрегатом до стратегічної ракети комплексу СС-19 «Сатана».

Бронетанкова i автомобільна техніка представлена зразками як минулого століття, так і сучасними. Це, зокрема, БМП-1; БРДМ-1; БРДМ-2; БТР-50ПК; БТР-70; БТР-80; танк Т-55; танк Т-64; танк Т-80; танк ПТ-76; танк IC-2; танк IC-3; танк M4 А2 «Шерман» (США); танк Т-34-85; танк PzKpfw III (Німечина).

Авіаційна техніка представлена літаками МІГ-23, МІГ-23 БН, МІГ-29 та вертольотом МI-24.

Відвідувачам пропонується оглянути корабельний якір зразка 1939 року від трофейного німецького корабля зі складу Дунайської флотилії, наданий прикордонниками Дунайського прикордонного загону у 1995 році.

В музей також передані на зберігання бойові прапори Академії Збройних Сил України, Національної академії оборони України, Військового гуманітарного інституту та штандарт Національної академії оборони України. 


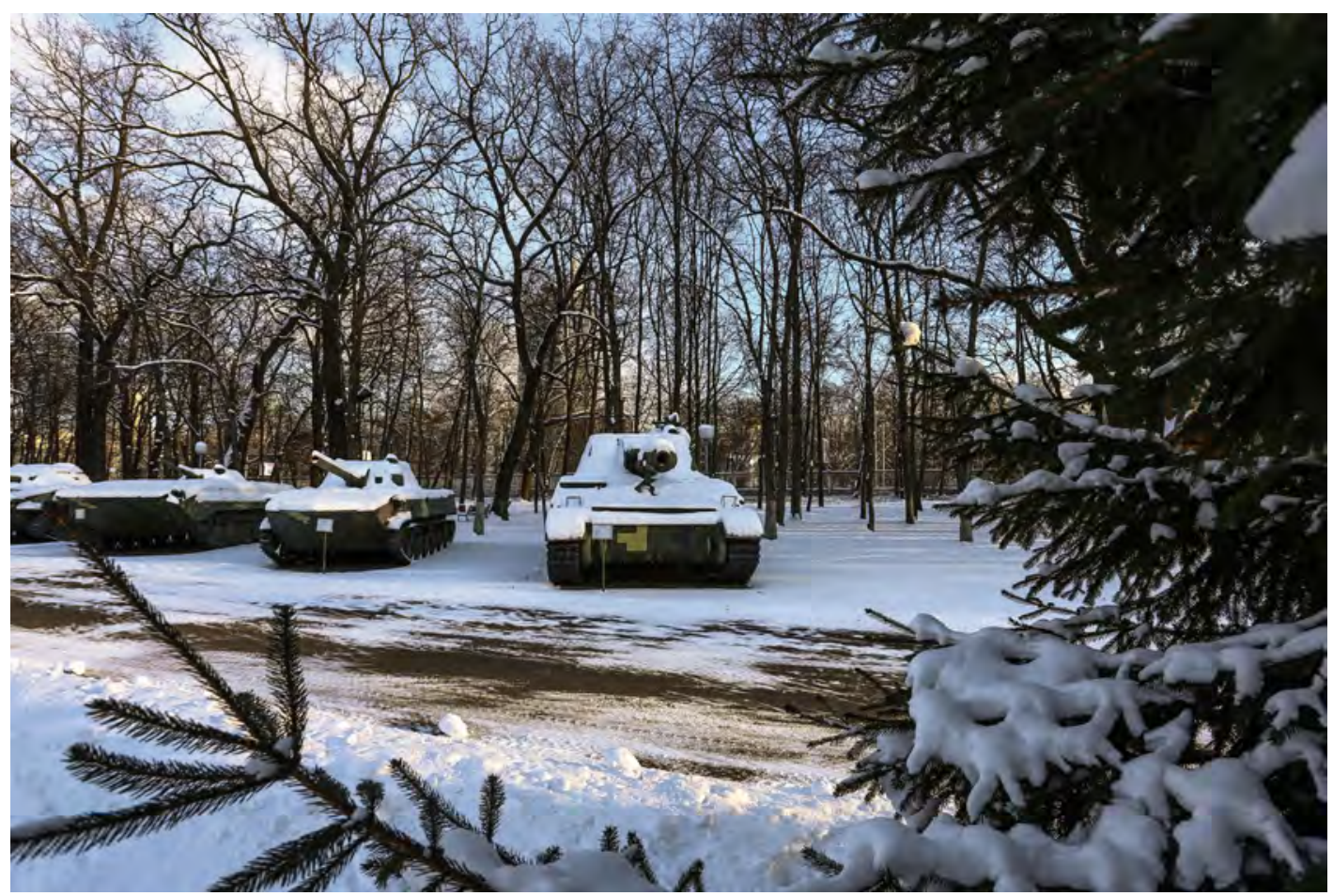

Кожний експонат музею має свою історію створення і походження. Безумовно цінним серед експонатів є середній танк часів Другої світової війни «М4А2 Шерман». В термін $з 7$ жовтня по 2 листопада 2004 року підводно-археологічною експедицією під керівництвом директора Департаменту підводної спадщини Інституту археології Національної академії наук України С.О. Воронова в акваторії річки Гнилий Тікич в південній частині села Нагірна Жашківського району Черкаської області було виявлено і піднято об'єкт підводної спадщини України - середній танк «M4A2 Шерман». Він $є$ одним із танків, отриманих Радянським урядом зі США в період 19421944 років за ленд-лізом. При опрацюванні архівних документів було виявлено, що цей танк входив до складу танкового полку 45-ї механізованої бригади 5-го механізованого корпусу 6-ої танкової армії 1-го Українського фронту. Екіпаж було укомплектовано на залізничній станції Вапнярка за добу до бою в складі чотирьох членів екіпажу (неповний склад). До екіпажу бойової ма- шини увійшли жителі місцевих сіл, які не мали бойового досвіду, і які, скоріш за все, до цього американських танків не бачили взагалі. Командир - молодший лейтенант О.I. Морозов - недавній випускник танкової школи. В зв'язку із складними погодними умовами із 45 танків від місця формування до бойової позиції дійшла 21 машина (вузькі гусениці «американців» в'язли в грязюці). В останню мить перед загибеллю заряджаючий встиг подати снаряд у ствол.

Цей об'єкт було підбито 2 лютого 1944 року на кризі посеред річки двома влучаннями замаскованої в селянській хаті самохідної артилерійської установки Вермахту. На той час частини Червоної армії вели бойові дії з ліквідації прориву частин 5-ої танкової дивізії СС «Вікінг» Вермахту по завершенню Корсунь-Шевченківської операції. Снарядами було перебито ліву гусеницю і збито башту танка. Три члени екіпажу загинули на місці (в травні 1944 року поховані місцевими жителями в братській могилі). Механік-водій був поранений, 
добу переховувався в місцевих жителів i наступного дня був виявлений і розстріляний підрозділом СС (похований у братській могилі біля села).

Танк було виявлено на глибині 3 метри. Стан об’єкту 80\% збереженості. Поряд на дні, $з$ правого боку, знайдено башту. Ліва гусениця - пошкоджена. Також виявлено боєкомплект (5 снарядів калібру 75-мм, один в стволі), який знешкоджено саперами. Були відсутні зенітний та бортовий кулемети, частина внутрішнього обладнання машини, фрагменти двигуна, паливні баки, верхні люки та радіостанція, особисті речі екіпажу.

На честь 60-річчя визволення України від нацистських загарбників Інститут археології НАНУ передав об'єкт підводної спадщини України танк «М4A2 Шерман» на баланс Центрального музею Збройних Сил України, а згодом він був переданий для експонування до Національної академії оборони України. 20 листопада 2004 року відбулася перша урочиста демонстрація танка, відреставрованого на Київському ремонтно-механічному заводі. Високому гостю цього заходу військовому аташе США полковнику Джону Конону була вручена гільза, знайдена в «Шермані», як символ спільної боротьби проти нацизму. Цей експонат є єдиним в Україні винятково цінним і рідкісним зразком бронетанкової техніки часів другої Світової війни.

Одним із незвичайних експонатів музею НУОУ є льотний шолом, подарований під час відвідин першим космонавтом України Л.К. Каденюком. Почесні регалії цього високого гостя не поміщаються в один рядок: український льотчик-випробувач 1-го класу, генерал-майор авіації, народний депутат України 4-го скликання, Народний Посол України, Герой України, Президент Аерокосмічного товариства України, Почесний доктор Чернівецького національного уні- верситету імені Ю. Федьковича... Перший і єдиний космонавт незалежної України Л.К. Каденюк пройшов інженерну та льотну підготовку за програмою «Буран» як його командир та підготовку в NASA до космічного польоту на американському космічному кораблі багаторазового використання «Колумбія» місії STS-87 як фахівець 3 корисного навантаження, а у період з 19 листопада по 5 грудня 1997 року здійснив космічний політ за цією програмою.

Окремої уваги надають в музеї особистим речам людей, які працювали та навчалися в університеті. Важливим надбанням музею $€$ речі людини великої мужності і яскравої, незвичайної долі В. Д. Лавриненкова. Він закінчив у 1941 році Чугуївську школу військових льотчиків, під час Другої світової війни здійснив 448 бойових вильотів, у 134 повітряних боях збив особисто - 35 та у складі групи - 11 літаків противника, двічі був удостоєний звання Героя Радянського Союзу. Не тільки перемоги в боях, але й непрості випробування випали на його долю: полон, втеча 3 товарного вагона під час перевезення до табору, боротьба проти нацистів у лавах партизанського загону. Після війни В.Д. Лавриненков служив у військах протиповітряної оборони, з 1977 року був начальником штабу і заступником начальника Цивільної оборони Української РСР, а з 1984 року до останніх днів - радником начальника академії протиповітряної оборони Сухопутних військ.

В експозиції музею особливе місце займає кітель Героя України генерал-майора А.Т. Ковальчука. Закінчивши у 2004 році Національну академію оборони України за спеціальністю «бойове застосування та управління діями підрозділів (частин, з'єднань) Сухопутних військ», А.Т. Ковальчук здобув кваліфікацію офіцера військового управління оперативно-тактичного рівня. 
У 2005-2006 роках брав участь у Миротворчій місії в Косово, у 2011 році служив на посаді начальника штабу вертолітного загону в Ліберії. Свою участь в антитерористичній операції полковник А.Т. Ковальчук розпочав на посаді командира 80-ї окремої аеромобільної бригади, частини якої в червні-липні 2014 року в боях звільняли Лиман, Миколаївку та Слов'янськ. Потім десантники під керівництвом полковника А. Т. Ковальчука здійснили марш у напрямку населеного пункту Щастя 3 метою допомоги 3-й батальйонній тактичній групі. Згодом підрозділи спільно деблоковували Луганський аеропорт, при цьому командир бригади був поранений, проте продовжив виконувати завдання.

19 липня 2014 року за особисту мужність і героїзм, виявлені при захисті державного суверенітету та територіальної цілісності України А.Т. Ковальчук був нагороджений орденом Богдана Хмельницького III ступеня, а 10 жовтня 2015 року — орденом Богдана Хмельницького II ступеня. Звання Герой України було вручено Президентом України під час параду на Хрещатику 3 нагоди 25-ї річниці Незалежності України 24 серпня 2016 року. Не зупинившись на досягнутому, у 2018 році генерал-майор А.Т. Ковальчук здобув ступінь магістра державного управління у Національному університеті оборони України ім. Івана Черняховського та 3 рук військового аташе британського посольства отримав меч королеви Великої Британії Слизавети II як найкращий випускник Національного університету оборони України 2018 року.

Також особливе місце серед експонатів музею зайняли особисті речі викладача кафедри підготовки офіцерів запасу полковника С.П. Корінного, який тричі брав участь у бойових діях у Республіці Афганістан. У 1985-1987 роках у якості радника командуючого 3 армійського корпусу Аф- ганської армії. Брав участь у плануванні та проведенні близько 40 військових операцій. У червні - липні 1988 року у складі оперативної групи під керівництвом генерала армії В.І. Варенникова, у вересні 1989 року - у складі групи представників Генерального штабу Радянської армії.

В експозиції представлений колаж фотографій полковника О.В. Матвієнка та його особисті речі, які використовувалися під час виконання Місії ООН в Республіці Південний Судан у 2017-2018 роках. У місії він відповідав за повітряні перевезення у рамках проведення заходів із підтримання миру в цій африканській країні.

Низка стендів музею присвячена виконанню бойових завдань особовим складом НУОУ під час проведення антитерористичної операції та операції Об'єднаних сил на сході України. Окреме місце посідають матеріали про загиблих офіцерів навчального закладу. У виставковій шафі експонується магістерська робота генерал-полковника Г.П. Воробйова, який у 2002-2004 роках був слухачем оперативно-стратегічного факультету, а в 2016-2017 роках начальником Національного університету оборони України імені Івана Черняховського. Кандидат історичних наук Г.П. Воробйов значної уваги приділяв розвитку матеріально-технічної бази університету і музею зокрема. Кавалер трьох орденів Богдана Хмельницького. Бойовий генерал Г.П. Воробйов, будучи з 18 листопада 2009 року по 17 січня 2014 року командувачем Сухопутних військ Збройних Сил України, а з 16 лютого 2014 року - першим заступником начальника Генерального штабу ЗС України, в.о. командувача АТО, водночас був людиною виняткової скромності. За словами генерала армії С. Т. Полторака, тогочасного Міністра оборони, Г.П. Воробйов відмовився від представлення до нагороди орденом Богдана Хмельницького першого сту- 
пеня, надаючи першість своїм підлеглим. Цю нагороду, що була присвоєна посмертно за вагомий особистий внесок у зміцнення обороноздатності і безпеки Української держави, бездоганне виконання військового і службового обов'язку, високий професіоналізм одержав батько. Іменем Г.П. Воробйова названо вулицю, прилеглу до НУОУ, якою часто прямують відвідувачі музею.

Щорічно в музеї проводиться понад 200 екскурсій та 70 візитів іноземних делегацій. Враження про музей фіксують у книзі почесних відвідувачів університету. Також в музеї постійно проводяться екскурсії для слухачів університету та його випускників, військовослужбовців строкової служби різних військових частин. Музей відіграє особливе місце у військово-патріотичному вихованні школярів та студентів міста Києва, які є постійними відвідува- чами музею. Завдяки здатності завідувача музею М.О. Ткаченка, головного зберігача фондів С.Є. Борисенка, зберігача фондів П.О. Домбровської генерувати і втілювати нові ідеї, експозиції музею постійно оновлюються та підтримуються у належному стані. Планується розширення міжмузейного партнерства, комунікації та взаємообміну, розробляються нові теми експозицій. Сучасні інформаційні технології розширюють стіни музею, збільшують сферу його впливу, допомагають вийти із закритого простору і стати реальною частиною буття університету, Перед музеєм Національного університету оборони України, як і перед іншими вітчизняними військовими музеями, постає завдання постійно адаптуватися до вимог XXI століття, щоб бути актуальними для нової доби та сучасного способу життя.

\section{ВИКОРИСТАНІ ЛІТЕРАТУРА}

1. Закон України «Про музеї та музейну справу». Режим доступу: https://zakon.rada.gov. ua/laws/show/249/95-вр\#Text

2. Про затвердження Положення про організацію діяльності військових музеїв, музеїв (кімнат) бойових традицій у Збройних Силах України. Наказ міністерства оборони України від 17 липня 2018 року N 343 Режим доступу: https://ips.ligazakon.net/document/ MUS30356? an=2

3. Указ Президента України від 22 березня 2000 року N 489/2000 «Про невідкладні заходи щодо розвитку музеїв України». Режим доступу: https://zakon.rada.gov.ua/laws/ show/489/2000\#Text

\section{REFERENS}

1. Zakon Ukrainy «Pro muzei ta muzeinu spravu». Rezhym dostupu: https://zakon.rada.gov. ua/laws/show/249/95-вр\#Text

2. Pro zatverdzhennia Polozhennia pro orhanizatsiiu diialnosti viiskovykh muzeiv, muzeiv (kimnat) boiovykh tradytsii u Zbroinykh Sylakh Ukrainy. Nakaz ministerstva oborony Ukrainy vid 17 lypnia 2018 roku N 343 Rezhym dostupu: https://ips.ligazakon.net/document/MUS30356?an=2

3. Ukaz Prezydenta Ukrainy vid 22 bereznia 2000 roku N 489/2000 «Pro nevidkladni zakhody shchodo rozvytku muzeiv Ukrainy». Rezhym dostupu: https://zakon.rada.gov.ua/laws/ show/489/2000\#Text 
Seheda S. P., Doctorof Historical Sciences, Associate Professor, Chief of the Research Center for Military History

National Defense University of Ukraine (Kyiv, Ukraine)

ORCID: https://orcid.org/0000-0002-7763-1324

Andriiako A.M.

\section{MILITARY HISTORY MUSEUM - A REAL PART OF THE EXISTENCE OF THE NATIONAL DEFENCE UNIVERSITY OF UKRAINE NAMED AFTER IVAN CHERNIAKHOVSKYI}

National Defence University of Ukraine named after Ivan Cherniakhovskyi (NDUU) is a higher military educational institution with unique exhibits in the collection of its' Military history museum. There are personal belongings of people who worked and studied at the University, as well as cold steel and firearms, military equipment of the Second World War and of today. Each exhibit of the museum has its'own unique history.

The directors of the museum of NDUU were I.M. Meshkov (1992-2008), Lieutenant Colonel S.M Ivanenko (2008-2010), Colonel A.M. Andriiako (2010-2014), M.O. Tkachenko (from 2014 to the present). Ministers of Defence, Chiefs of General Staffs of Ukraine and other states, representatives of Ukrainian and foreign military educational institutions, mayors of Ukrainian cities and famous politicians left comments of admiration in the Museum Book of Honorary Guests.

Among the exhibits of the Museum there are 592 unique photographs which represent the life of the University since its'creation as a military educational and scientific institution to the present day. Visitors from all over Ukraine, foreign delegations and Kyiv schoolchildren have the opportunity to get acquainted with the military history of the National Defence Universityof Ukraine named after Ivan Cherniakhovskyi, which is illustrated by the museum's exhibits.

Key words: Military history museum, collection, firearms, cold steel, exposition. 